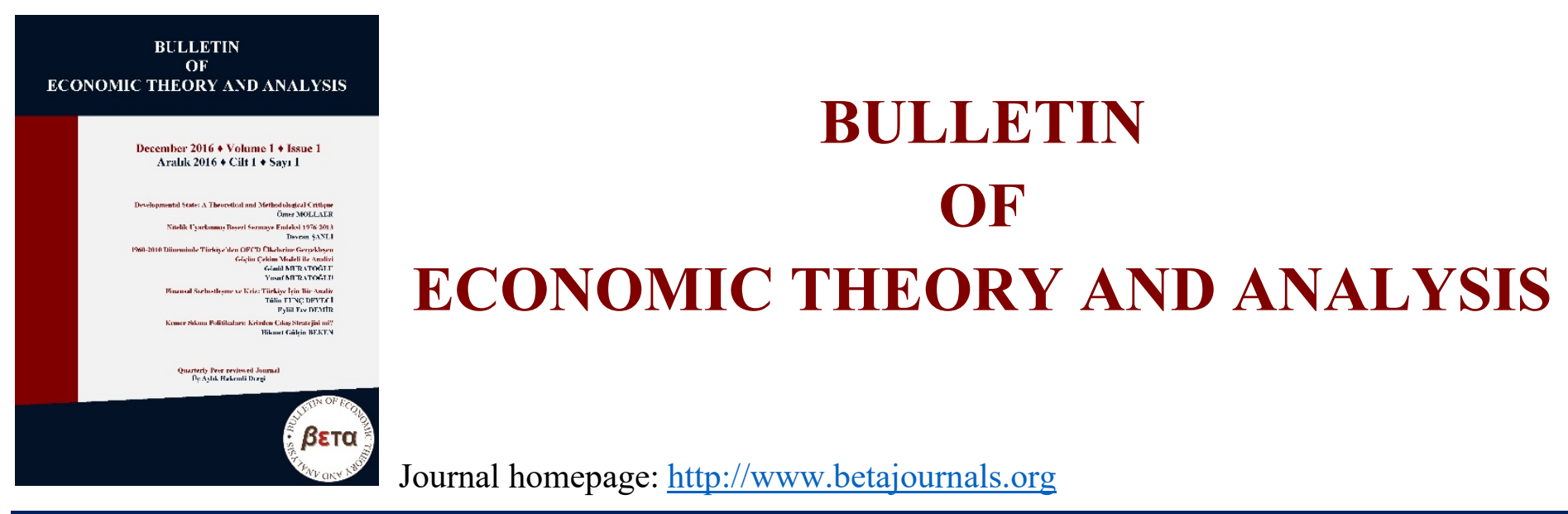

\title{
Yeni Bir Kurum Olarak Strateji ve Bütçe Başkanlığı: Kısa Bir Değerlendirme
}

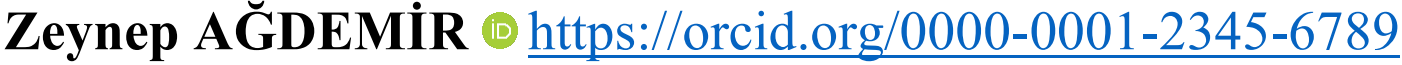

To cite this article: Ağdemir, Z. (2021). Yeni Bir Kurum Olarak Strateji ve Bütçe Başkanlığ1: Kısa Bir Değerlendirme. Bulletin of Economic Theory and Analysis, 6(2), 91-113.

Received: 20 Nov 2021

Accepted: 13 Dec 2021

Published online: 31 Dec 2021

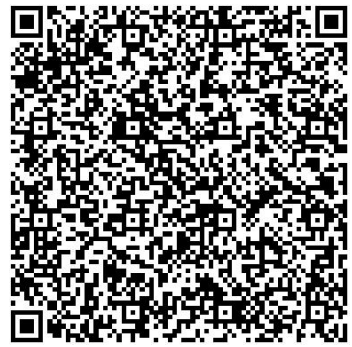

CAll right reserved 


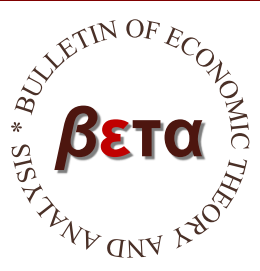

\section{Bulletin of Economic Theory and Analysis}

Volume VI, Issue 2, pp. 91-113, 2021

http://www.betajournals.org

Original Article / Araştırma Makalesi

Received / Alınma: 20.11.2021 Accepted / Kabul: 13.12.2021

\section{Yeni Bir Kurum Olarak Strateji ve Bütçe Başkanlığı: Kısa Bir Değerlendirme}

\section{Zeynep AĞDEMIR ${ }^{\mathrm{a}}$}

${ }^{a}$ Dr. Öğr. Üyesi, Kırşehir Ahi Evran Üniversitesi İ̈BF Maliye Bölümü, Kırşehir, TÜRKIYE

() https://orcid.org/0000-0001-2345-6789

\section{ÖZ}

2018 yılında Cumhurbaşkanlığı Hükümet Sistemine geçiş ile birlikte kamu ekonomi yönetiminde önemli değişimler gerçekleşmiştir. Ekonomi yönetiminde bazı bakanlıklar birleşirken, bazı bakanlıklar tasfiye edilmiş, bütçe yetkisi Cumhurbaşkanına geçmiştir. Strateji ve Bütçe Başkanlığı yeni bir kurum olarak örgütlenmiştir. CHS ile birlikte kamu ekonomi yönetiminde gerçekleşen değişimler değerlendirilirken yeni bir kurum olan Strateji ve Bütçe Başkanlığının görev ve yetkileri ile teşkilat yapısı detaylı bir değerlendirmeye tabi tutulmamıştır. Strateji ve Bütçe Başkanlığ 1 ile Kalkınma Bakanlığı ve Maliye Bakanlığı arasında görev paylaşımının detayları incelenmemiştir. Bu bağlamda, bu çalışmanın amacı Strateji ve Bütçe Başkanlığının görev ve yetkileri ile teşkilat yapısı bakımından Kalkınma Bakanlığı ile Maliye Bakanlığına bağlı Bütçe ve Mali Kontrol Genel Müdürlüğü ile olan ilişkisinin irdelenmesi kurumlar arasındaki ortaklıkların ve farklılıkları ortaya konularak Strateji ve Bütçe Başkanlığının anlaşılmaya çalışılmasıdır. Bu çerçevede çalışma, ilgili kurumların görev ve yetkileri ile teşkilat yapılarını incelemiştir.
Anahtar

Kelimeler

Kalkınma

Bakanlığg,

Bütçe ve Mali

Kontrol Genel

Müdürlüğ̈̈, Kamu

Mali Yönetim ve

Dönüşüm Genel

Müdürlüğü,

Strateji ve Bütçe

Başkanlığ 1

JEL Kodu

H1, H6, H83

ÍLETIŞİM Zeynep AĞDEMİR $₫$ zeynepagdemir@ahievran.edu.tr $\equiv$ Kurşehir Ahi Evran Üniversitesi İİF Maliye Bölümü, Kırşehir, Türkiye 


\section{A Brief Evaluation of the Presidency of Strategy and Budget as a New Institution}

\begin{abstract}
Significant changes in the management of the public economy occurred as a result of the transition to the Presidential Government System in 2018. While some ministries were incorporated into the economy management, others were dissolved and the President was given budget responsibility. The Presidency of Strategy and Budget was established as a new institution. While evaluating the changes in public economy management brought about by CHS, the Presidency of Strategy and Budget (a new agency) responsibilities and authorities, as well as its organizational structure, were not thoroughly evaluated. The task distribution between the Presidency of Strategy and Budget, the Ministry of Development, and the Ministry of Finance has not been reviewed in detail. In this context, the purpose of this study is to examine the relationship between the Ministry of Development and the General Directorate of Budget and Financial Control within the Ministry of Finance in terms of the the Presidency of Strategy and Budget's duties and authorities and organizational structure, as well as to attempt to comprehend the Presidency of Strategy and Budget by highlighting the institutions' partnerships and differences. The study analyzed the key institutions' responsibilities, authorities, and organizational structures in this setting.
\end{abstract}

Keywords

The Ministry of

Development,

The General

Directorate of

Budget and

Financial Control,

The General

Directorate of

Public Financial

Management and

Transformation, and

Presidency of

Strategy and Budget

JEL Classification H1, H6, H83

\section{Giriş}

2018 yılında Cumhurbaşkanlığg Hükümet Sistemine (CHS) geçiş ile birlikte 1 Sayılı Cumhurbaşkanlığı Kararnamesi (CK) kamu ekonomi yönetiminde köklü değişimler getirmiştir. Bütçe Kanun Tasarısı, Bakanlar Kurulu tarafından hazırlanırken, CHS ile birlikte artık Cumhurbaşkanı tarafından Bütçe Teklifi biçiminde hazırlanmaktadır. Bu çerçevede bütçe sürecinde aktif rol üstelenecek yeni kurum olarak Strateji ve Bütçe Başkanllğ 1 (SBB) kurulmuştur. Hazine Müsteşarlığı ve Maliye Bakanlığı birleştirilerek Hazine ve Maliye Bakanlığı halini almış, Aile ve Sosyal Politikalar Bakanlığı ile Çalışma ve Sosyal Güvenlik Bakanlığı birleştirilmiş, Çalışma, Sosyal Hizmetler ve Aile Bakanlığı olarak düzenlenmiştir. 21 Nisan 2021 CK ile birleştirilen bakanlık Çalışma ve Sosyal Güvenlik Bakanlığı ile Aile ve Sosyal Hizmetler Bakanlığı olarak tekrar ikiye ayrılmıştır. Gıda, Tarım ve Hayvancılık Bakanlığı ile Orman ve Su İşleri Bakanlığı birleştirilerek Tarım ve Orman Bakanlığı biçiminde örgütlenmiştir. Ulaştırma Denizcilik ve Haberleşme Bakanlığ 1 Ulaştırma ve Altyapı Bakanlığ1 adını almıştır. Bilim, Sanayi ve Teknoloji Bakanlığı ile Kalkınma Bakanlığının bazı bölümleri birleştirilerek Sanayi ve Teknoloji Bakanlığı olmuştur. Gümrük ve Ticaret Bakanlığı ile Ekonomi Bakanlığı birleştirilerek Ticaret Bakanlığı olmuştur. Cumhurbaşkanlığına bağlı olarak çeşitli alanlarda faaliyet gösterecek Ofis ve Politika Kurulları kurulmuştur. CHS'nin kamu 
ekonomi yönetiminde yarattığı dönüşümlerin incelenmesine ilişkin Oyan (2019), Bedirhanoğlu (2019), Ün (2021), Temel (2019), Çalışkan vd., (2020), Küçükaycan, vd., (2019), Akbey (2020), Yegen (2020), Yavuz vd., (2021), Ercan (2021), Coşkun ve Yıldırım (2018) gibi pek çok çalışma yapılmıştır. Ancak bu çalışmalar içerisinde bütçe süreci için önemli bir kurum olan SBB'den ya hiç bahsedilmemiş ya da Coşkun ve Yıldırım (2018) ile Yegen'in (2020) çalışmaları dışında oldukça tali bir yerde kalmıştır. Bahsedilen çalışmalar kapsamında, Strateji ve Bütçe Başkanlığının görevleri ve yapısı hakkında yapılan değerlendirmeler aşağıdaki gibi s1ralanabilir:

-SBB, Hazine ve Maliye Bakanlığından bütçeye dair bazı yetkileri almış, Cumhurbaşkanlığı kapsamında bütçe hazırlık ve uygulanmasına ilişkin yetkileri almak üzere kurulmuştur. Önceden ayrı ayrı Maliye Bakanlığı ve Kalkınma Bakanlığı tarafından hazırlanan Orta Vadeli Program (OVP) ve Orta Vadeli Mali Plan (OVMP) Hazine ve Maliye Bakanlığı ile SBB'nin birlikte hazırladığı metinler olmuştur. Bütçe ve Mali Kontrol Genel Müdürlüğü (BÜMKO) ikiye ayrılarak bütçe kısmı SBB’ye aktarılırken mali kontrol kısmı Muhasebat Genel Müdürlüğü ile birleştirilmiştir (Ün, 2021: 308-9).

- CHS ile birlikte Kalkınma Bakanlığı ve BÜMKO ilga edilmiş, Kalkınma Bakanlığının yetkileri SBB'ye devredilmiş, BÜMKO'nun kontrol yetkileri yeni kurulan Muhasebat ve Mali Kontrol Genel Müdürlüğü'ne taşınmıştır (Akbey, 2020: 14).

-SBB "plan ve program hazırlığı ve takibi, bütçe hazırlık ve uygulaması gibi mali yönetim sisteminin işleyişine ilişkin önemli görevleri de bünyesinde” toplamış BÜMKO’nun görevleri Hazine ve Maliye Bakanlığına devredilmiştir (Yılmaz ve Akdeniz, 2020: 95-96).

-OVP ve OVMP Strateji ve Bütçe Başkanlığı ile Hazine ve Maliye Bakanlığı tarafindan birlikte hazırlanacaktır. Ancak bu belgelerin hazırlanmasında kurumların ağırlıkları belirsizdir. CHS ile birlikte BÜMKO ikiye ayrılmış bütçe kısmı SBB'ye mali kontrol kısmı ise Muhasebat ve Mali Kontrol Genel Müdürlüğüne verilmiştir (Yegen, 2020: 158-159).

- SBB, Devlet Planlama Teşkilatı (DPT) ile Hazine ve Maliye Bakanlığının mini hali olmuştur (Oyan, 2019: 122; Bedirhanoğlu, 2019: 4).

- Stratejik planlama konusunda DPT ve Kalkınma Bakanlığının görev ve yetkileri Strateji ve Bütçe Başkalığına aktarılmıştır (Coşkun ve Yıldırım, 2018: 13).

Görüldüğü üzere SBB'nin, Maliye Bakanlığı BÜMKO, Kalkınma Bakanlığı ve onun önceki biçimiyle DPT'nin yerini aldığı söylenmektedir. Ancak SBB ile bu bakanlıklar arasındaki ilişkinin nasıl kurulduğu bahsedilen çalışmalar çerçevesinde net değildir ve yapılan 
yeni düzenlemeler de dikkate alınarak bu ilişkiye dair güncellemelerin yapılması gerekmektedir. Öncelikle BÜMKO tamamıyla kapatılmamış, bazı yetkileri SBB’ye verilerek Hazine ve Maliye Bakanlığı kapsamında Kamu Mali Yönetim ve Dönüşüm Genel Müdürlüğü (KMYD) olarak yeniden yapılandırılmıştır. Diğer yandan, DPT-Kalkınma Bakanlığı ile SBB ilişkilerinin de yeniden gözden geçirilmesi gerekmektedir. SBB Kalkınma Bakanlığının hangi görev ve yetkilerini almıştır? SBB, Kalkınma Bakanlığından farklı olarak ne tür görev ve yetkilere sahiptir? Bu ve buna benzer soruların cevaplanması için bu çalışmanın temel amacı, yeni bir kurum olarak Strateji ve Bütçe Başkanlığının Kalkınma Bakanlığı ve Maliye Bakanlığı ile ilişkisi üzerinden görev ve yetkileri ile teşkilat yapısının anlaşılmaya çalışılmasıdır. Çalışma, Maliye Bakanlığı içerisinde BÜMKO’ya odaklanarak bu ayrımı yapmaya çalışacaktır. Bu bağlamda, yazı öncelikle DPT ve Kalkınma Bakanlığı arasındaki görev ve yetkiler bağlamında nasıl bir ilişki kurulduğunu, SBB’nin Kalkınma Bakanlığından hangi görev ve yetkileri devraldığını ve teşkilat yapısının nasıl yapılandırıldığını ele alacaktır. Ardından ise BÜMKO ve KMYD arasında görev, yetki ve teşkilat yapısı bağlamında kurulan ilişki biçimi ve SBB'nin bu çerçevede nasıl yapılandırıldı̆̆ı anlaşılmaya çalışılacaktır.

\section{DPT, Kalkınma Bakanlığı ile Strateji ve Bütçe Başkanlığı}

Bilindiği üzere, 8 Haziran 2011 tarihli Resmi Gazetede yayımlanan 641 sayılı Kalkınma Bakanlığının Teşkilat Ve Görevleri Hakkında Kanun Hükmünde Kararname (KHK) ile DPT yerine Kalkınma Bakanlığı kurulmuştur. DPT’nin kuruluş esaslarını düzenleyen 540 sayılı Devlet Planlama Teşkilatı Kuruluş ve Görevleri Hakkında Kanun Hükmünde Kararname ile Kalkınma Bakanlığının kuruluş esaslarını düzenleyen 641 sayılı KHK karşılaştırıldığında, Kalkınma Bakanlığının görevlerinin neredeyse hepsini DPT'den aldığını söylemek mümkündür. Kalkınma Bakanlığının DPT’den görevleri bağlamında ayrıldığı noktalar ise üç başlıkta incelenebilir. DPT’nin kuruluş amacı “kaynakların verimli kullanılması ve kalkınmanın hızlandırılması amacıyla ülkenin ekonomik, sosyal ve kültürel planlama hizmetlerinin bir bütünlük içerisinde etkin, düzenli ve süratli olarak görülebilmesi” iken Kalkınma Bakanlığı için böyle bir hedef düzenlenmemiştir. Bu durumun temelinde Kalkınma Bakanlığının DPT gibi planlama odaklı bir biçimde yapılandırılmaması yatmaktadır. İkinci olarak, DPT kalkınma planı ve yıllık program hazırlarken Kalkınma Bakanlığı "makroekonomik, sektörel (sosyal ve iktisadi) ve bölgesel gelişme alanlarında, ulusal ve yerel düzeyde analiz ve çalışmalar yaparak kalkınma planı, orta vadeli program, yıllık programlar, stratejiler ve eylem planlar" hazırlamakla görevlendirilmiş, yani DPT'den daha geniş bir çerçevede özellikle de bölgesel düzeyde planlama faaliyeti yürütmekle görevlendirilmiştir. 
Başka bir deyişle, Kalkınma Bakanlığı bölgesel düzeyde çalışmalara dâhil iken, DPT’nin böyle bir görevi bulunmamaktadır. Son olarak DPT 2000'li yıllarda yapılan değişikliklerle stratejik planlar arasında yönlendirme işlevine sahip iken, Kalkınma Bakanlığının bu işlevi daha da genişleterek uyumlaştırma ve yönlendirme birimi olarak yapılandırılmıştır (Övgün, 2011: 273274). Bu benzerlik ve farkl1lıkları Tablo 1'den izlemek mümkündür.

CHS ile birlikte Kalkınma Bakanlığı ilga edilerek bazı görevleri SBB’ye aktarılmıştır. Kalkınma Bakanlığının görevleri ve teşkilat yapısının SBB'ye aktarılma biçimi SBB'yi anlamamız açısından önemli görünmektedir. Tablo 1'den takip ederek her iki kurumun görevlerine bakacak olursak, SBB’nin Kalkınma Bakanlığının “üllkenin doğal, beşeri ve iktisadi her türlü kaynak ve imkânlarını tespit ederek, takip edilecek iktisadi, sosyal ve kültürel politika ve hedeflerin belirlenmesinde hükümete müşavirlik yapmak” görevine sahip olmadığını görmek mümkündür. SBB, "Cumhurbaşkanı tarafindan belirlenen hedef, ilke ve amaçlar çerçevesinde" Cumhurbaşkanlığı programı (eski yıllık program), orta vadeli mali plan, orta vadeli program ve sektörel plan ve programları hazırlamak ile yükümlü tutulmuştur. SBB'nin plan ve program hazırlanırken önceliği "Cumhurbaşkanı tarafindan belirlenen hedef, ilke ve amaçlar" olarak belirlenmiştir. SBB, kendisine verilen bu görevleri Politika Kurullarının görüşünü alarak hazırlamak ile mükellef kılınmıştır. Böylelikle üst politika metinlerinin temel stratejisi Cumhurbaşkanı ve yine Cumhurbaşkanı tarafından belirlenecek Politika Kurulları merkezinde belirlenecektir. Diğer yandan, Kalkınma Bakanlığından farklı olarak SBB orta vadeli mali planı da hazırlamakla yükümlü tutulmuştur. Bu görev daha önce Maliye Bakanlığına bağlı BÜMKO tarafından yapılmaktaydı. Başka bir deyişle SBB, Maliye Bakanlığının bazı görevlerini de almıştır. SBB ve BÜMKO arasındaki ilişkiyi, izleyen başlıkta inceleyeceğiz. SBB, Kalkınma Bakanlığg gibi orta vadeli program, Cumhurbaşkanlığ1 programı, Cumhurbaşkanı yıllık programı ile sektörel plan ve programlar ve kamu idarelerinin stratejik planları arasındaki uygunluğu sağlamak için yönlendirme, izleme ve değerlendirme yapmaktadır. ${ }^{1}$ Ancak, SBB'nin, Kalkınma Bakanlığı görevleri içerisinde yer alan özel sektörü yönlendirme görevi de yoktur, SBB plan, program ile kamu idareleri arasındaki uyum konusunda yönlendirici role sahiptir.

Yeni sistemle birlikte “OVP'lerin politika ve önceliklerin ortaya konulduğu, kamu ve özel sektör için yönlendirici, kamuoyuna bilgi sağlayan belgelere dönüşememiş" (Yılmaz ve

\footnotetext{
${ }^{1}$ 24.7.2018 tarihinde Resmi Gazete'de yayımlanan 30488 sayılı Strateji ve Bütçe Başkanlığı Teşkilatı hakkındaki 13. Cumhurbaşkanlığı Kararnamesi esas alınarak değerlendirilmiştir.
} 
Akdeniz, 2020: 100) olmasının bir sebebi de SBB'nin özel sektörü yönlendirme görevinin olmaması olarak yorumlanabilir.

SBB, Kalkınma Bakanlığından farklı olarak Türkiye'nin kalkınma deneyimlerinden hareketle gelişmekte olan ülkelere kalkınma konusunda teknik destek sağlamak, yardımcı olmak ve yol göstermek konusunda yeni bir misyona sahiptir. SBB’nin Kalkınma Bakanlığından ayrılan diğer bir özelliği, kalkınma ajansları ile ilgili görevi olmaması, bölgesel planları hazırlamaktan ziyade görevinin, sadece bölgesel kalkınma planlarının üst politika metinleri ile uyumunu sağlamak olarak belirlenmesidir. Kalkınma Bakanlığının Kalkınma Ajansları ile ilgi yetkileri Sanayi ve Teknoloji Bakanlığına, bölgesel kalkınma ile ilgili görevleri ise Ticaret Bakanlığına aktarılmıştır. Böylelikle, ulusal ve bölgesel planların hazırlanması süreci birbirinden ayrılmıştır².

SBB’nin görevleri arasında, İslam İşbirliği Teşkilatı Ekonomik ve Ticari İşbirliği Daimi Komitesi (İSEDAK) ile ilgili maddeler bulunmaktadır. İslami ülkeler ile ticari, ekonomik çeşitli ilişkilerin iyileştirilmesi ve bu konuda mali kaynak ayrılması İSEDAK'ın sekretaryasını yapmak ve ülkeler arasındaki koordinasyon çalışmaları SBB'nin görevleri arasında sayılmıştır. Kalkınma Bakanlığı Dış Ekonomik İlişkiler Genel Müdürlüğünün de İSEDAK ile ilişkileri bulunmaktadır. Bu bağlamda, Kalkınma Bakanlığının Dış Ekonomik İlişkiler Genel Müdürlüğü yerine SBB'de İSEDAK ve Uluslararası Kalkınma İşbirliği Genel Müdürlüğü kurulmuştur (Strateji ve Bütçe Başkanlığı, kişisel görüşme, Aralık, 2021). Buradaki temel fark bizce SBB ile birlikte İSEDAK vurgusunun öne çıkmasıdır. 641 sayılı Kalkınma Bakanlığının Teşkilat ve Görevleri Hakkında Kanun Hükmünde Kararname bakanlığın görevleri içerisinde doğrudan İSEDAK'a referans vermezken, 13 sayılı Strateji ve Bütçe Başkanlığı Teşkilatı hakkındaki Cumhurbaşkanlığı Kararname iki madde ile bu hususu düzenlemiştir.

Kalkınma Bakanlığı ile SBB teşkilat yapısı Şekil 1 ve Şekil 2 izlendiğinde, Kalkınma Bakanlığının genel müdürlüklerinin küçük isim değişiklikleri ile SBB'nin teşkilat yapısına girdiğini görüyoruz. SBB’nin görevleri üzerinden de tespit ettiğimiz üzere, Kalkınma Bakanlığından farklı olarak, SBB bölgesel kalkınmaya dönük bir teşkilatlanmaya sahip değildir. Kalkınma Bakanlığındaki İstihdam ve Çalışma Hayatı Daire Başkanlığı ile Gelir Dağılımı ve Sosyal İçerme Daire Başkanlığı kaldırılıp, Çalışma Hayatı ve İstihdam Sosyal Hizmetler Dairesi kurulmuştur. Gelir Dağılımı ifadesinin teşkilat isminden kaldırılması oldukça

\footnotetext{
2 Kalkınma Bakanlığının bu görevi Sanayi ve Ticaret Bakanlığı Bölgesel Gelişme Yapısal Uyum Genel Müdürlüğüne aktarılmıştır (Strateji ve Bütçe Başkanlığı, kişisel görüşme, Aralık, 2021).
} 
dikkat çekicidir. Dış Ekonomik İlişkiler Genel Müdürlüğünün yerini İSEDAK ve Uluslararası Kalkınma İşbirliği Genel Müdürlüğü almış görünmektedir.

SBB'nin görev ve yetkilerinin diğer kısımları bütçe bağlamında olduğu için SBB ile BÜMKO arasındaki ilişkinin nasıl kurulduğuna, BÜMKO'nun CHS ile birlikte nasıl yapılandırıldığına bakmak faydalı olacaktır. 
Tablo 1

DPT, Kalkınma Bakanlı̆̆ı ile Strateji ve Bütçe Başkanlı̆̆ının Görevleri

\begin{tabular}{|c|c|c|}
\hline DPT & Kalkınma Bakanlığı & Strateji ve Bütçe Başkanlığı \\
\hline $\begin{array}{l}\text { Amaç: "Bu Kanun Hükmünde Kararnamenin amacı, kaynakların verimli } \\
\text { kullanılması ve kalkınmanın hızlandırılması amacıyla ülkenin ekonomik, } \\
\text { sosyal ve kültürel planlama hizmetlerinin bir bütünlük içerisinde etkin, } \\
\text { düzenli ve süratli olarak görülebilmesi için Devlet Planlama Teşkilatının } \\
\text { kurulmasına, teşkilat ve görevlerine dair esasları düzenlemektir." }\end{array}$ & Amaç: X & Amaç: X \\
\hline $\begin{array}{l}\text { "Ülkenin doğal, beşeri ve iktisadi her türlü kaynak ve imkanlarını tespit } \\
\text { ederek, takip edilecek iktisadi, sosyal ve kültürel politika ve hedeflerin } \\
\text { belirlenmesinde Hükümete müşavirlik yapmak," }\end{array}$ & DPT ile aynı & $\mathrm{X}$ \\
\hline $\begin{array}{l}\text { "Hükümetçe belirlenen amaçlar doğrultusunda kalkınma planları ile yıllık } \\
\text { programları hazırlamak," }\end{array}$ & $\begin{array}{l}\text { "Hükümetçe belirlenen amaçlar doğrultusunda makro ekonomik, sektörel } \\
\text { (sosyal ve iktisadi) ve bölgesel gelişme alanlarında, ulusal ve yerel düzeyde } \\
\text { analiz ve çalşşalar yaparak kalkınma planı, orta vadeli program, yıllık } \\
\text { programlar, stratejiler ve eylem planları hazırlamaktadır," }\end{array}$ & $\begin{array}{l}\text { Cumhurbaşkanı tarafindan belirlenen temel hedef, ilke ve amaçlar } \\
\text { çerçevesinde kalkınma planı, Cumhurbaşkanlığı programı, orta vadel } \\
\text { program, orta vadeli mali plan, Cumhurbaşkanlığ yıllık programı ile } \\
\text { sektörel plan ve programları, ilgili kamu idareleri ile Cumhurbaşkanlı̆ } \\
\text { bünyesinde bulunan Politika Kurullarının görüuşlerini de almak suretiyle } \\
\text { hazırlamak ve makro dengelerini oluşturmak," }\end{array}$ \\
\hline $\begin{array}{l}\text { "Bakanlıkların ve kamu kurum ve kuruluşlarının iktisadi, sosyal ve kültürel } \\
\text { politikayı ilgilendiren faaliyetlerinde koordinasyonu sağlamak, uygulamayı } \\
\text { etkin bir biçimde yönlendirmek ve bu konularda Hükümete müşavirlik } \\
\text { yapmak," }\end{array}$ & DPT ile aynı & $\begin{array}{l}\text { "Cumhurbaşkanı tarafindan belirlenen temel hedef, ilke ve amaçlar } \\
\text { çerçevesinde stratejik planların hazırlanması, uygulanması ve izlenmesine } \\
\text { ilişkin genel ilke, esas ve usulleri tespit etmek; kamu idarelerinin stratejik } \\
\text { planlarının kalkınma planı, Cumhurbaşkanı tarafindan belirlenen } \\
\text { politikalar ve orta vadeli programda belirlenen hedef ve amaçlara uygun } \\
\text { olarak hazırlanmasını sağlamak, uygulamasını izlemek ve sonuçların } \\
\text { değerlendirmek," }\end{array}$ \\
\hline $\begin{array}{l}\text { "Uluslararası kuruluşlarla iletişim içerisinde çalşsarak ileriye dönük } \\
\text { stratejiler geliştirmek ve topluma perspektif sağlayan politika önerilerini } \\
\text { katıllımcı bir yaklaşımla belirleyerek özel kesim için orta ve uzun dönemde } \\
\text { belirsizlikleri giderici genel bir yönlendirme görevini yerine getirmek," }\end{array}$ & DPT ile aynı & $\mathrm{X}$ \\
\hline $\begin{array}{l}\text { "Kalkınma planlarının ve yıllık programların başarı ile uygulanabilmesi için } \\
\text { ilgili kurum ve kuruluşların ve mahalli idarelerin kuruluş ve işleyişlerinin } \\
\text { iyileştirilmesi konusunda görüss ve tekliflerde bulunmak," }\end{array}$ & $\begin{array}{l}\text { “...kurumsal kapasiteyi her yönüyle geliştirme amaciyla gerekli her türlü } \\
\text { tedbiri almak; kurumsal stratejik yönetim ve planlama konularında merkezi } \\
\text { uyumlaştırma ve yönlendirme fonksiyonunu yerine getirmek,” }\end{array}$ & $\mathrm{X}$ \\
\hline $\begin{array}{l}\text { "Kalkınma planlarının ve yıllık programların uygulanmasını izlemek } \\
\text { ve koordine etmek, değerlendirmek ve gerektiğinde kalkınma planlarında ve } \\
\text { yıllık programlarda usulüne uygun değişiklikler yapmak," }\end{array}$ & DPT ile aynı & $\begin{array}{l}\text { "Cumhurbaşkanı tarafindan belirlenen temel hedef, ilke ve amaçla } \\
\text { çerçevesinde kalkınma planı, orta vadeli program, orta vadeli mali plan } \\
\text { Cumhurbaşkanlığı programı, Cumhurbaşkanı yılllık programı ile sektöre } \\
\text { plan ve programları uygulanmasını izlemek, değerlendirmek, gerektiğinde } \\
\text { (a) bendinde belirtilen usule uygun olarak değişiklik yapmak veya teklif } \\
\text { etmek," }\end{array}$ \\
\hline $\begin{array}{l}\text { "Maliye, para, dış ticaret ve kambiyo politikalarının kalkınma planı ve yıllık } \\
\text { programların hedefleriyle uyum içinde uygulanması konusunda Hükümete } \\
\text { müşavirlik yapmak," }\end{array}$ & DPT ile aynı & $\mathrm{X}$ \\
\hline
\end{tabular}




\begin{tabular}{|c|c|c|}
\hline $\begin{array}{l}\text { "Özel sektör ve yabancı sermaye faaliyetlerinin plan hedef ve amaçlarına } \\
\text { uygun bir şekilde yürütülmesini düzenleyecek teşvik ve yönlendirme } \\
\text { politikaların genel çerçevesini hazırlamak ve Hükümete teklif etmek," }\end{array}$ & DPT ile aynı & $\mathrm{X}$ \\
\hline $\begin{array}{l}\text { "Kalkınmada öncelikli yörelerin daha hızlı bir şekilde gelişmesini sağlayacak } \\
\text { tedbirleri tespit ve teklif etmek, uygulamayı izlemek ve koordine etmek," }\end{array}$ & DPT ile aynı & $\mathrm{X}$ \\
\hline $\begin{array}{l}\text { "Kalkınma planı ve yillık programlardaki ilke ve hedeflere uygun olarak, } \\
\text { uluslararası ekonomik kuruluşlarla ilişkilerin geliştirilmesinde, temas ve } \\
\text { müzakerelerin yürütülmesinde gerekli görüş ve tekliflerde bulunmak," }\end{array}$ & DPT ile aynı & $\begin{array}{l}\text { "Gelişmekte olan ülkelerin kalkınma çabalarına yardımcı olmak amacıyla bu } \\
\text { ülkelere yönelik teknik yardım faaliyetlerini yürütmek", v) "Kalkınma } \\
\text { alanında ilgili ulusal ve uluslararası kuruluşlarla işbirliği program ve } \\
\text { projelerini hazırlamak, koordine etmek ve gerektiğinde yürütmek" y) } \\
\text { "Ülkemizin kalkınma tecrübelerinin, başta komşu ülkeler olmak üzere, } \\
\text { işbirliği içinde olunan gelişmekte olan ülkelere aktarılmasına destek olmak," }\end{array}$ \\
\hline "Bölgesel veya sektörel bazda gelişme programları hazırlamak," & DPT ile aynı & $\begin{array}{l}\text { "Bölgesel, çok taraflı ve ikili kalkınma, ekonomik ve ticari işbirliğinin } \\
\text { kalkınma planları ve Cumhurbaşkanlığı yıllık programlarında belirtilen ilke } \\
\text { hedef ve politikalarla uyumlu ve etkili bir şekilde yürütülmesi için gerekl } \\
\text { çalışmaları yapmak," }\end{array}$ \\
\hline $\mathrm{X}$ & $\begin{array}{l}\text { "Kalkınma ajanslarının koordinasyonunu sağlamak ve bunlarla ilgili iş ve } \\
\text { işlemleri yürütmek," }\end{array}$ & $\mathrm{X}$ \\
\hline $\mathrm{X}$ & $\begin{array}{l}\text { "Bilgi toplumuna ilişkin politika, hedef ve stratejiler hazırlamak, bu alanda } \\
\text { kamu kurum ve kuruluşları, sivil toplum örgütleri ile özel sektör arasındaki } \\
\text { koordinasyonu sağlamak ve uygulamayı etkin bir biçimde yönlendirmek." }\end{array}$ & $\mathrm{X}$ \\
\hline & "Mevzuatla bakanlı̆ga verilen diğer görev ve hizmetleri yapmak," & $\mathrm{X}$ \\
\hline $\mathrm{X}$ & $\mathrm{X}$ & $\begin{array}{l}\text { "Kamu yatırım projelerinin uygulanmasına ilişkin usul ve esaslar } \\
\text { belirlemek, bu projelerin etkili, etkin, ekonomik ve verimli olmasını ve } \\
\text { zamanında tamamlanmasını sağlamak üzere gerekli tedbirleri alarak } \\
\text { uygulamayı yönlendirmek, uygulamayı izlemek, yıl içinde gerekli değişiklik } \\
\text { işlemlerini yapmak," }\end{array}$ \\
\hline $\mathrm{X}$ & $\mathrm{X}$ & $\begin{array}{l}\text { "Kamu yatırımlarına ilişkin analiz ve araştırmalar yapmak, kamu } \\
\text { kuruluşlarının yürüteceği projelerin geliştirilmesine destek vermek, projeler } \\
\text { analiz etmek," }\end{array}$ \\
\hline $\mathrm{X}$ & $\mathrm{X}$ & $\begin{array}{l}\text { "Kamu yatırımlarının gerçekleştirilmesinde uygun finansman modeller } \\
\text { geliştirmek, kamu-özel işbirliği projelerini analiz etmek," }\end{array}$ \\
\hline
\end{tabular}

Kaynak. 641 sayılı Kalkınma Bakanlı̆̆ının Teşkilat ve Görevleri Hakkında Kanun Hükmünde Kararname”, "540 sayılı Devlet Planlama Teşkilatı Kuruluş ve Görevleri Hakkında Kanun Hükmünde Kararname ile 13 sayılı Strateji ve Bütçe Başkanlığı Teşkilatı hakkındaki Cumhurbaşkanlığı Kararnamesinin karşılaştırılmasııdır. X, satırda bulunan görevin ilgili kurumda olmadığını belirtmektedir. 


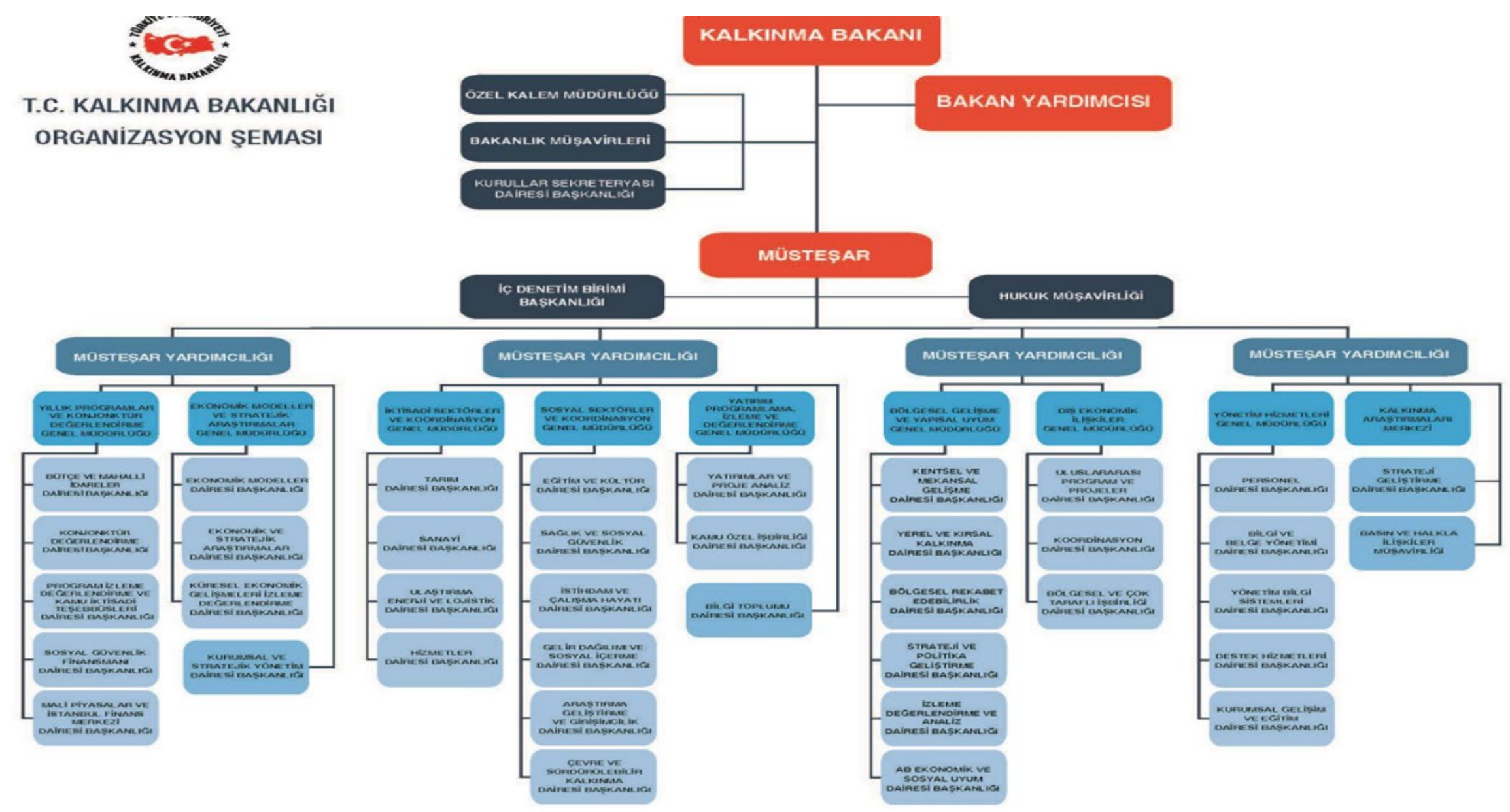

Şekil 1. Kalkınma Bakanlığı Teşkilat Şeması. Kalkınma Bakanlığı 2014 Faaliyet Raporu s. 4'ten doğrudan alınmıştır. 


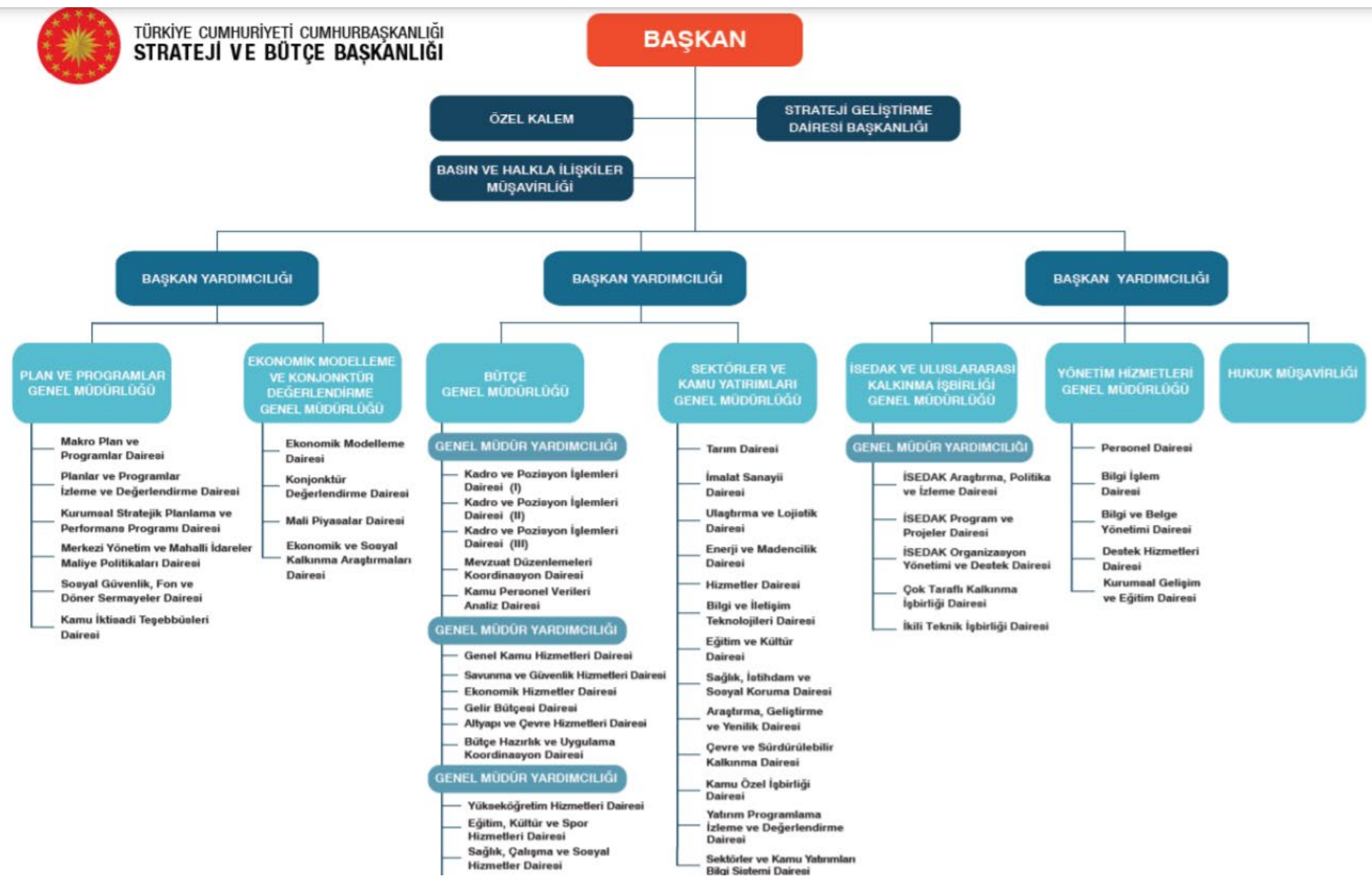

Şekil 2. Strateji ve Bütçe Başkanlığı Teşkilat Şeması. Strateji ve Bütçe Başkanlığı 2018 Yılı Faaliyet Raporu s. 6'dan doğrudan alınmıştır. 


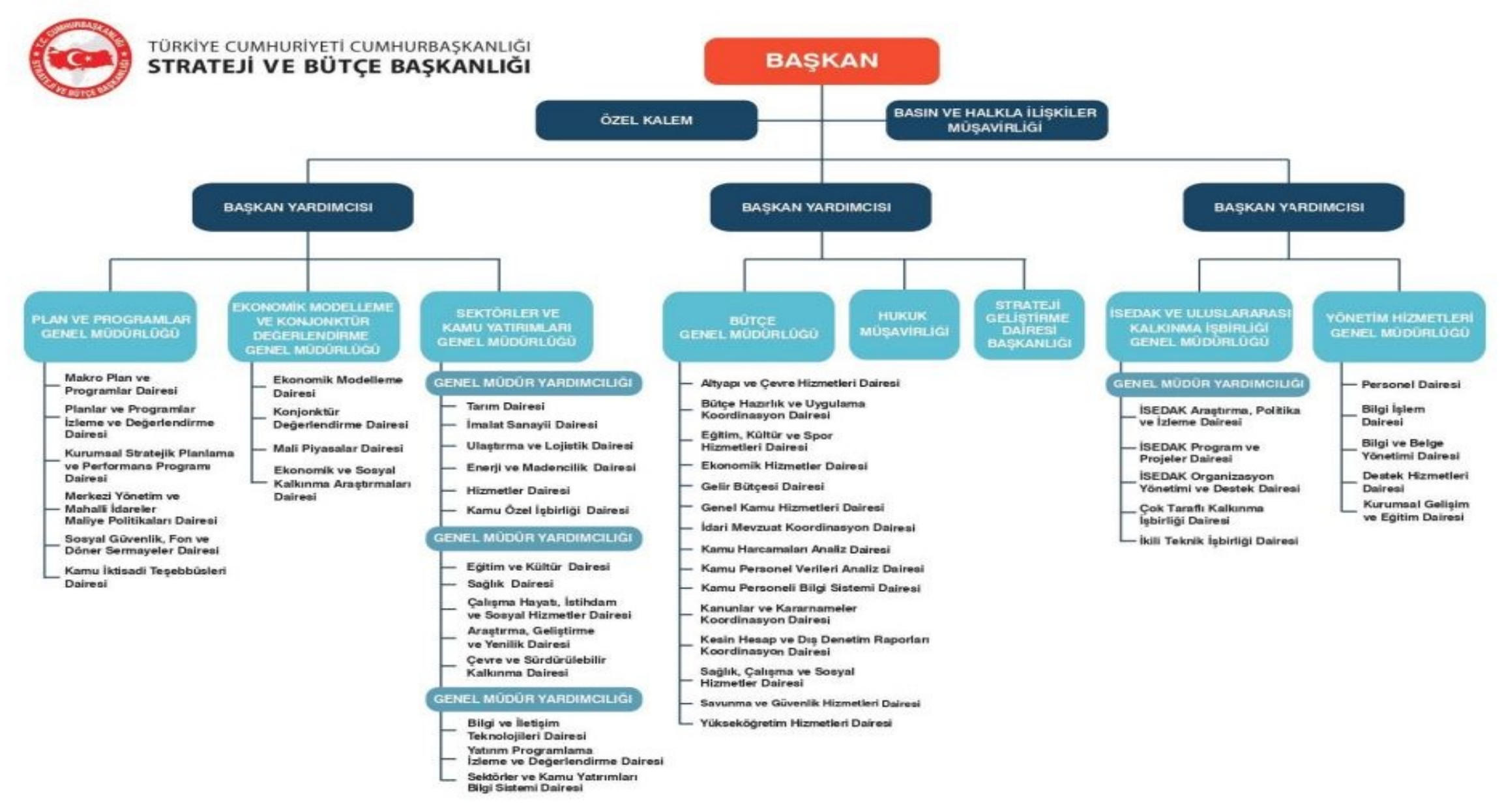

Şekil 3. Strateji ve Bütçe Başkanlığı Yeni Teşkilat Şeması. Strateji ve Bütçe Başkanlığı 2022 Yılı Performans Programı s. 7'den doğrudan alınmıştır (aktr. Strateji ve Bütçe Başkanlığı, kişisel görüşme, Aralık, 2021). 


\section{Bütçe ve Mali Kontrol Genel Müdürlüğü, Kamu Mali Yönetim ve Dönüşüm Genel Müdürlüğü ile Strateji ve Bütçe Başkanlığı}

Bütçe ve Mali Kontrol Genel Müdürlüğü (BÜMKO) 1936 yılında 2996 sayılı Kanun ile kurulmuş olup, uzun süre teşkilatının görevlerinde önemli değişiklik olmamış, 1983 yılında 178 sayılı Kanun ile görevleri daha kapsamlı biçimde tanımlanmıştır. Cumhurbaşkanlığı Hükümet Sistemine geçiş sonrasında 10 Temmuz 2018 tarihli 1 Sayılı Cumhurbaşkanlığı Kararı ile mülga edilmiş, Bütçe ve Mali Kontrol Genel Müdürlüğü ile Muhasebat Genel Müdürlügü, Muhasebat ve Mali Kontrol Genel Müdürlüğü olarak birleştirilmiştir. 7 Ağustos 2019 tarihli “43 sayılı Bazı Cumhurbaşkanlığı Kararnamelerinde Değişiklik Yapılması Hakkında Cumhurbaşkanlığı Kararnamesi” ile Muhasebat ve Mali Kontrol Genel Müdürlüğü kapatılarak Muhasebat Genel Müdürlüğü yeniden kurulmuş, Kamu Mali Yönetim ve Dönüşüm Genel Müdürlüğü (KMYD) adı altında yeni bir genel müdürlük yapılandırılmıştır (Hazine ve Maliye Bakanlığı, 2021).

Tablo 2'den izleneceği üzere BÜMKO'nun bazı yetkileri KMYD ile SBB arasında paylaştırılmış, bazı yetkiler ortaklaştırılmıştır. Dikkati çeken ilk husus, SBB’nin Merkezi Bütçe Kanun Teklifinin hazırlanmasında kamu harcamalarına dair ağırlık kazanan rolüdür. Başka bir deyişle, bütçe ilke esas ve usullerini tespit etmek; yedek ödenek taleplerini incelemek ve Cumhurbaşkanının onayı ile uygulamak; gelir, ödenek ve nakit verilerinin kamu harcamaları stratejisi bağlamında değerlendirilmesi ve Merkezi Bütçe Kanun Teklif Taslağını hazırlamak BÜMKO’nun SBB'ye aktarılan görevleri olmuştur. KMYD ise SBB’nin Merkezi Bütçe Kanun Teklif Taslağının hazırlanmasında kullanılacak Gelir Bütçesi Teklifi Taslağını ${ }^{3}$ hazırlamak ile yükümlü kılınmıştır. Yani CHS geçiş ile birlikte, Maliye Bakanlığı tarafından hazırlanan Merkezi Bütçe Kanun Teklifinin, harcama kısmı SBB'ye aktarılarak, gelir kısmı ise Hazine ve Maliye Bakanlığında bırakılarak parçalanmış gibi görünmektedir.

BÜMKO'dan KMYD'ye devredilen ve SBB'nin görevleri içerisinde olmayan hususlar ise kamu alımlarına dair politika geliştirmek, iç kontrol, taşıt alımı ve kamu kadrolarına dair çeşitli görevleri yerine getirmek sayılabilir. Dikkat çeken diğer bir husus kamu personel politikasında KMYD’nin SBB'ye görüş veren biçiminde konumlandırılması, SBB’nin ise kamu personeli politikası konusunda karar veren olarak görevlendirilmesidir. Diğer bir ifadeyle

\footnotetext{
${ }^{3}$ Gelir Politikaları Genel Müdürlüğü 2006 yılında Maliye Bakanlığı bünyesinde herhangi bir birimin görevi kapsamında bulunmayan "gelir politikası geliştirmek" görevini Gelir İdaresi Başkanlığından alarak kurulmuştur (Barbak, 2010: 29). İleride de ele alınacağı üzere, gelir analizi BÜMKO’nun değil, Gelir Politikaları Genel Müdürlüğünün yetkisi içerisindedir. 1 sayılı CBK öncesinde BÜMKO gelir bütçesi konusunda Gelir Politikaları Genel Müdürlüğü ile koordineli çalışmaktadır. 1 Sayılı CBK ile Gelir Politikaları Genel Müdürlüğü kapatıldığı için bu görev KMYD’ye geçmiştir (Strateji ve Bütçe Başkanlığı, kişisel görüşme, Aralık, 2021).
} 
“BÜMKO’nun yürüttüğü kadro rejimini denetim altında tutma, sevk ve idare etme işlevi” SBB'ye aktarılmıştır (Albayrak, 2020: 18). Ancak 2 sayılı Genel Kadro ve Usulü Hakkında Cumhurbaşkanlığı Kararnamesinde yapılan düzenlemeler sonucunda, kamuda kadro, izin, değişiklik gibi tüm işlemler Cumhurbaşkanlığına bağlanmıştır. Dolayısıyla SBB’nin “Kadro ve Pozisyon İşlemleri Daireleri” Cumhurbaşkanlığı İdari İşler Başkanlığına aktarılmıştır (Strateji ve Bütçe Başkanlığı, kişisel görüşme, Aralık, 2021). Bu değişimin SBB teşkilat yapısındaki etkisini Şekil 3 üzerinden izlemek mümkündür.

Diğer yandan, BÜMKO’nun genel yönetim gelir-gider ve harcamalarının takip edilmesi amacıyla genel yönetim içerisindeki kurumlardan yardım alan dernek ve vakıf gibi kuruluşların mali durumlarına bilgi isteme görevinin, KMYD ve SBB'nin yetkileri arasında yer almaması oldukça dikkat çekicidir.

SBB ve KMYD’nin ortak görevleri de bulunmaktadır. "Cumhurbaşkanı tarafından belirlenen temel hedef, ilke ve amaçlar çerçevesinde" ve Politika Kurullarının görüşlerine başvurarak OVP ve OVMP'yi hazırlamak KMYD ve SBB'nin ortak görevleri olarak belirlenmiştir. 5 Eylül 2021 tarihinde Resmi Gazetede yayımlanan 2022-2024 OVP dışında önceki 3 yıl OVP'si Yeni Ekonomi Programı (YEP) adı altında Hazine ve Maliye Bakanlığının Ekonomik Programlar ve Araştırmalar Genel Müdürlüğü (EPA) koordinasyonunda hazırlamıştır. Ancak 25 Mayıs 2021 tarihli düzenleme ile OVP ve OVMP, OVP adı altında birleştirilmiş ve tek bir doküman olarak yayınlanmaya başlamış bu kapsamda 2022-2021 OVP, OVMP ve OVP'nin birleştirilmiş hali olarak SBB tarafından hazırlanmış, EPA'ya görüş alınmak üzere gönderilmiştir (Hazine ve Maliye Bakanlığı, kişisel görüşme, Kasım, 2021).

SBB ile KMYD'nin ortak görevlerinden bir diğeri kamu harcamalarında tasarrufun sağlanması konusundadır. Kamu harcamalarının "etkinlik, etkililik, ekonomiklik ve verimlilik" ilkeleri çerçevesinde yapılması için kamu kurumlarının uyması gereken kurallar koymak, tedbirler almak ve izlemek KMYD'nin görevi iken benzer biçimde SBB için kamu harcamalarında tasarrufun sağlanması görevi tanımlanmıştır. SBB kamu harcama politikasını etkileyecek düzenlemeleri Hazine ve Maliye Bakanlığı ile koordineli olarak izlemektedir. SBB ayrıca bütçe politikasının tutarlı ve etkili biçimde yürütülmesi, kamu istihdamı ve giderlere dair politika oluşturulması konusunda yetkilidir.

BÜMKO’nun görevlerinin KMYD ve SBB'ye paylaştırılma biçimi Tablo 3'te görüldüğü gibi SBB'nin teşkilat yapısına da yansımıştır. SBB, BÜMKO'dan Genel Kamu Hizmetleri Dairesi, Eğitim, Kültür Spor Hizmetleri Dairesi, Yükseköğretim Hizmetleri Dairesi, gibi kamu harcama dairelerini kendi teşkilat yapısına eklemiş, KMYD'de bu dairelere benzer 
teşkilatlanmaya gidilmemiştir. Savunma ve Güvenlik Hizmetleri Dairesi, Ekonomik Hizmetler Dairesi, Altyapı ve Çevre Hizmetleri Dairesi isimleri değişerek BÜMKO'dan SBB'ye geçen daireler olmuştur (Strateji ve Bütçe Başkanlığı, kişisel görüşme, Aralık 2021).Bu bize SBB'nin kamu harcamaları, KMYD’nin kamu gelirleri konusunda öne çıkan görev ve yetkilerini hatırlatmaktadır.

Keza bu bağlamda, 1 Sayılı CBK ile Gelir Politikaları Genel Müdürlüğü kapatıldığı için BÜMKO'da olmayan Gelir Analizleri Dairesi KMYD çatısı altında kurulmuştur. Kamu Harcamaları Dairesi ise BÜMKO'da olmayan ancak SBB'de yeni kurulan bir daire olmuştur (Strateji ve Bütçe Başkanlığı, kişisel görüşme, Aralık, 2021).

BÜMKO’nun Sağlık ve Sosyal Güvenlik, İş Hukuku, Mahalli İdareler Dairesi, SBB’ye Sağlık, Çalışma ve Sosyal Hizmetler Dairesi olarak KMYD’ye Sağlık ve Sosyal Güvenlik Dairesi ile Sosyal Güvenlik Mevzuatı ve İş Hukuku Dairesi olarak aktarılmıştır. İlgili alanlarda mevzuata ilişkin görevler KMYD'de kalırken, bütçe uygulamasına ilişkin görevler SBB'de kalmıştır. İdari Mevzuat Koordinasyon Dairesi ile Kanunlar ve Kararnameler Koordinasyon Dairesi hem SBB'de hem de KMYD'de bulunan dairelerdir (Strateji ve Bütçe Başkanlığg, kişisel görüşme, Aralık 2021). Teşkilat yapısındaki bu ortaklık SBB gibi KMYD’nin kamu harcamaları mevzuatına dair görevlerinin sonucu olarak yorumlanabilir.

BÜMKO’nun Bütçe Politikası ve Uluslararası İlişkiler Dairesi, Bütçe Politikası Koordinasyon Dairesi olarak KMYD’ye, Bütçe Hazırlık ve Uygulama Koordinasyon Dairesi olarak SBB'ye aktarılmıştır. Uluslararası İlişkiler SBB'de diğer dairelerin koordinasyonu ile yürütülmektedir. BÜMKO’da Personel Mevzuat Dairesi (I) (II), KMYD’de Personel Mevzuat Dairesi ve SBB'de Kadro ve Pozisyon İşlemleri Dairesi (I) (II) (III) biçimini almıştır. Ancak son düzenleme ile birlikte Şekil 3 üzerinden izlenebileceği üzere bu dairenin yerini Kamu Personel Verileri Analiz Dairesi, Kamu Personeli Bilgi Sistemi Dairesi alırken, Kesin Hesap ve Dış Denetim Raporları Koordinasyon Dairesi, Gelir Bütçesi Dairesi yeni kurulan daireler olmuştur (Strateji ve Bütçe Başkanlığı, kişisel görüşme, Aralık, 2021). Kamu personeli konusunda önemli yetkilerin doğrudan Cumhurbaşkanlığına bağlanması da oldukça dikkat çekici bir gelişmedir. 
Tablo 2

Bütçe ve Mali Kontrol Genel Müdürlüğü, Kamu Mali Yönetim ve Dönüşüm Genel Müdürlüğü ve Strateji ve Bütçe Başkanlı̆̆l Görevlerinin

\section{Karşılaştırılması}

\begin{abstract}
Bütçe ve Mali Kontrol Genel Müdürlüğü
"Genel bütçeye dahil daireler ile katma bütçeli kurulușların bütçe hazırlık çalışmaları sırasında göz önünde bulunduracakları teknik ilkeleri tespit etmek ve bütçe hazırlık çalışmalarını koordine etmek,"

"Kuruluşlarca hazırlanan bütçe tekliflerini inceleyerek bunların kalkınma planları ve yıllık programlara uygunluğunu sağlamak, teklifleri konsolide ederek bütçe kanunu tasarılarını gerekçesi ile birlikte hazırlamak,"

"Bütçenin kalkınma planları ve yıllık programlarda belirlenen hedefler doğrultusunda ve takip edilen ekonomi ve maliye politikalarıyla uyumlu bir şekilde uygulanmasını sağlamak, uygulamaya ait bütçe işlemlerini bir şekild,

"Yıl içinde ortaya çıkan ihtiyaçlar üzerine dairelerince teklif edilecek ek ve olağanüstü ödenek taleplerini ve bütçe uygulamasına dair diğer kanun tekliflerini inceleyerek bunlardan uygun bulunanları tasarı haline getirmek,"

"Ödenek, gelir ve nakit verilerini derleyerek bunları harcama politikaları açısından değerlendirmek ve uygulamayı yönlendirmek; genel bütçeye dahil dairelerle katma bütçeli idarelerin ve fonların her mali yılın başında o yıl için hazine nakit akımını da dikkate alarak ayrıntılı harcama programlarını yapmak, gerekli görülen hallerde bu programlan değiștirmek ve ilgili kuruluşlar nezdinde uygulamaları izlemek,"

"Kamu harcamalarında tasarruf sağlanması, tutarlı, dengeli ve etkili bir bütce politikasnn yürütülmesi amaciyla kamu istihdam politikası ve bütçe politikasının yürutulmesi anacıyla kamu istihdam politikası ve giderlerle ilgili kann, thatk, karaname ve yönetmeliklerin uygulanmasını düzenlemek, standartları tespit etmek ve sınırlamalar
koymak; bu hususlarda tüm kamu kurum ve kuruluşları için uyulmas zorunlu düzenlemeleri yapmak ve tedbirleri almak,"

"Harcama politikalarını etkileyebilecek her türlü kanun, tüzük, kararname ve yönetmelik tekliflerini inceleyerek bunlar hakkında Bakanlığın görüşünü hazırlamak,"

"Maliye Bakanlığınca teklif edilecek kamu giderlerine ilișkin kanun, tüzük, kararname ve yönetmelik tasarılarını hazırlamak,"

"Yürürlükte bulunan mevzuatın mali hükümlerinin uygulanmasını yönlendirmek, bu konuda ortaya çıkacak her türlü meseleyi çözmek, tereddütleri gidermek,"
\end{abstract}

\section{Kamu Mali Yönetim ve Dönüşüm Genel Müdürlüği}

$\mathrm{X}$

"Kamu harcamaları ile devlet gelirlerinin kalkınma planı, orta vadeli program, orta vadeli mali plan ve Cumhurbaskanlığ şekilde uygulanmasını teminen gerekli her türlü tedbiri almak,"

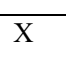

"Kamu harcamalarında etkinlik, etkililik, ekonomiklik ve verimlilik sağlamak amaciyla gerekli standartları tespit etmek ve sinırlamalar koymak; bu hususlarda tüm kamu kurum ve kurulusları için uyulması zorunlu düzenlemeleri yapmak, tedbirleri almak ve uygulamayı izlemek,"

"Harcamaları etkileyebilecek her türlü mevzuat taslaklarını inceleyerek bunlar hakkında Bakanlığın görüşünü hazırlamak,"

"Bakanlığın görev alanına giren hususlarda mevzuatta yer alan mali hükümlerin uygulanmasını yönlendirmek, bu konuda ortaya çıkabilecek her türlü meseleyi çözmek ve tereddütleri gidermek,"

\section{Strateji ve Bütce Baskanlı̆}

"Merkezi yönetim kapsamındaki kamu idarelerinin bütçe hazırlık çalışmaları sırasında uyacakları teknik ilke, esas ve usulleri tespit etmek ve bütçe hazırlık çalışmalarını koordine içinde yürütme,"

"Kamu idareleri tarafından hazırlanıp Başkanlığa gönderilen bütçe tekliflerini inceleyerek bunların kalkınma planı, Cumhurbaşkan tarafindan belirlenen hedef ve amaçlar, orta vadeli program, orta vadel mali plan, stratejik planlar, performans programları ile bütçe hazırlıklarına esas teknik ilke, esas ve usullere uygunluğunu sağlamak,"

"Bütçenin kalkınma planı, orta vadeli program, orta vadeli mali plan ve Cumhurbaşkanlığı yıllık programında belirlenen hedefler doğrultusunda maliye politikalarıyla uyumlu bir şekilde uygulanmasını sağlamak, uygulamaya ait bütçe işlemlerinin yapıılmasını sağlamak,"

uygulamaya ait bütçe işlemlerinin yapılmasını sağlamak," "Mali yıl içinde ortaya çıkan ihtiyaçlar üzerine kamu idareleri tarafinda "Mali yil icinde oraya chan intiyaclar üzerine kamu idarelen Cumhurbaşkanınca uygun bulunanları karşılamak,"

"Ödenek, gelir ve nakit verilerini derleyerek bunları harcama politikaları açısından değerlendirmek ve uygulamayı yönlendirmek,"

"Kamu harcamalarında tasarruf sağlanması, tutarlı, dengeli ve etkili bir bütçe politikasının yürütülnes

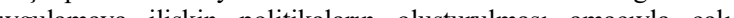
uygulanaya ilşk poun yämak; käzor tü düzenlemeyi inceleyerek, yapılacak düzenlemeleri koordine etmek,"

"Başkanlı̆̆ın görev alanına giren konularda hazırlanan mevzuat düzenlemelerine ilişkin olarak ilgili ihtisas birimlerinin de görüşünü almak suretiyle Başkanlığın görüşünü hazırlamak, mevzuat hazırlıkları ile görüş verilmesine ilișkin çalıșmalarda Başkanlığ temsil etmek ve katılım hususunda gerekli koordinasyonu sağlamak,"

(2)


"Kuruluşların gider taahhütlerini kontrol etmek ve hesaplarını tutmak, bunlara ilişkin sözleş̧me tasarılarını vize etmek,"

"Bütçenin geliştirilmesi, etkin ve verimli bir şekilde uygulanması yönünde araștırmalar yapmak veya yaptırmak ve gerekli tedbirleri almak,"

"Devlet harcamaları konusunda diğer mevzuat ile Maliye Bakanlığına verilen görevleri yapmak",

"Genel ekonomik politika ve stratejiler çerçevesinde kamu alımlarına ilişkin temel politikaları oluşturmak, bu konudaki kanun tasarılarının hazırlanmasında ilgili kurumlar arasında koordinasyonu sağlamak,"

"Kanun, kanun hükmünde kararname, bakanlar kurulu kararı, yönetmelik ve diğer mevzuatla kurulmuş fonlardan gerekli görülenlerin gelirlerinin toplanmasına, giderlerinin yapılmasına ilişkin esas ve usulleri tespit etmek, bütçe ile ilişkilerini düzenlemek, bütçelerinin hazırlanmasın sağlamak ve uygulanmasını izlemek; fonların gelir ve giderleri ile gelirlerinden yapılacak kesintilere ilişkin olarak esas, usul, miktar ve oranların belirlenmesi, 3 bunların tasfiyesi veya birleştirilmesi hakkınd bütçe kanunlarında yer alacak hükümler konusunda teklifler hazırlamak ve uygulamaya yönelik tedbirleri almak

"Kamu kurum ve kuruluşlarınca işletilen eğitim ve dinlenme tesisi, misafirhane, kreş, spor tesisi ve benzeri sosyal tesislerden yararlanacak olanlardan alınacak asgarî bedelleri belirlemek, bu yerlerden elde edilen gelirlerin kullanımına ilişkin esas ve usuller ile bunlara ilişkin düzenlemeleri yapmak,"

"Devlet memurları ve diğer kamu görevlileri ile bunların emekli, dul ve yetimlerinin (bakmakla yükümlü oldukları aile fertleri dahil) ve 18.6.1992 tarihli ve 3816 sayılı Kanun kapsamındaki yeșil kart sahiplerinin ayakta arillo

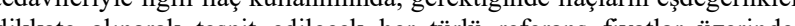
dikkate alc il bedellerinin odenmesini bedell odenecek ve odenmeyecek ilaçlar ile ilaçların reçetelenmesine ilişkin kuralları tespit etmek ve yeşil kat sahiplerinden, ayakta veya meskende tedavi halinde kullanılacak ila bedellerinin \% 20'sine kadar katılım payı alınmasını sağlamak ve bu hususlara ilişkin esas ve usulleri Sağlık Bakanlığının görüşünü almak suretiyle tespit etmek,"

"Orta Vadeli Mali Planı, Bütçe Çağrısı ve eki Bütçe Hazırlama Rehberin hazırlamak, standartları tespit etmek ve kamu idareleri arasında koordinasyonu sağlamak,"

"Merkezi Yönetim Bütçe Kanunu Tasarısını ve genel faaliyet raporun hazırlamak,"
"Kamu harcamalarında etkinlik, etkililik, ekonomiklik ve verimlilik sağlamak amaciyla gerekli standartları tespit etmek ve sinırlamalar koymak; bu hususlarda tüm kamu kurum ve kuruluşları için uyulmas zorunlu düzenlemeleri yapmak, tedbirleri almak ve uygulamayı izlemek,"

$\mathrm{X}$

"Kam

"Kamu harcamaları konusunda diğer mevzuat ile Bakanlığa verilen görevleri yapmak,"

"Genel ekonomik politika ve stratejiler çerçevesinde kamu alımlarına ilişsin temel politikaları oluşturmak,"

$\mathrm{X}$
misafirhane, çocuk bakımevi, kreş, spor tesisi ve benzeri sosyal tesislerden yararlanacak olanlardan alnacak bedelleri belirlemek, bu yerlerden elde edilen gelirlerin kullanımına ilişkin usul ve esaslar ile

"Cumhurbaşkanı tarafindan belirlenen temel hedef, ilke ve amaçlar cerçevesinde orta vadeli program hazırlıklarına katılmak ve orta vadeli mali plan ile sektörel plan ve programları, ilgili kamu idareleri ile Cumhurbaşkanlığı bünyesinde bulunan politika kurullarının görüşlerini de almak suretiyle Strateji ve Bütçe Başkanlığı ile müștereken hazırlamak ve makro dengelerini olușturmak,"

"Devlet gelirleri politikasının plan, program, genel ekonomik politika ve stratejiler çerçevesinde olusturulmasına ilișkin çalışmaları koordine etmek ve vergi yükü ile gelir tahminlerine yönelik analizler yapmak,"
"Kamu harcamalarında tasarruf sağlanması, tutarlı, dengeli ve etkili bir bütçe politikasının yürütülmesi ve kamu istihdamı ve giderlerle ilgili uygulamaya ilişkin politikaların oluşturulması amacıyla çalışmala yapmak; kamu harcama politikalarını etkileyebilecek her türlü düzenlemeyi inceleyerek, yapılacak düzenlemeleri koordine etmek," "Harcama ve bütçe politikalarının geliştirilmesine yönelik çalışmalar yapmak,"

"Harcama ve bütçe politikalarııın geliștirilmesine yönelik çalıșmalar yapmak,"

\section{$\mathrm{X}$}

"Merkezi yönetim kapsamındaki kamu idarelerine ait olan merkez yönetim bütçesi dışındaki diğer her türlü bütçe, fon, döner sermaye, özel hesap ve proje hesabı için genel ilke ve stratejileri tespit etmek, gerekli görülenler için bütçelerinin onaylanması zorunluluğu getirmek, görile pro lçin bü uygulamalarına youn vermek ve izlemek, harcamaların etkili, etkin,
ekonomik ve verimli olmasını sağlamak üzere gerekli tedbirleri almak,"

\section{$\mathrm{X}$}

$\mathrm{X}$

"Cumhurbaşkanı tarafindan belirlenen temel hedef, ilke ve amaçlar çerçevesinde kalkınma planı, Cumhurbaşkanlığı programı, orta vadeli program, orta vadeli mali plan, Cumhurbaşkanlığı yıllık programı ile sektörel plan ve programları, ilgili kamu idareleri ile Cumhurbaskanlı̆ bünyesinde bulunan Politika Kurullarınn görüslerini de almak suretiyle bünes hazırlamak ve makro dengelerini oluşturmak " "Hazine ve Maliye Bakanlığının oluşturduğu gelir tahminlerini esas
alarak hazırladığı gelir bütçesi teklifi taslağı ile kamu idarelerinin bütçe 


\begin{tabular}{|c|c|c|}
\hline & & $\begin{array}{l}\text { tekliflerini konsolide ederek merkezi yönetim bütçe kanun teklif taslağını } \\
\text { oluşturmak," }\end{array}$ \\
\hline $\begin{array}{lll} & \text { "Ödeneklerin kullanımına ilişkin esaslar ile ayrıntılı harcama } & \text { ve } \\
\text { finansman programlarının hazırlanmasına, uygulanmasına } & \text { ve } \\
\text { uygulamanın izlenmesine ilişkin usul ve esasları belirlemek," } & \\
\end{array}$ & e & $\mathrm{X}$ \\
\hline $\begin{array}{l}\text { "Mali yönetim ve iç kontrol süreçlerine ilişkin standart ve yöntemleri } \\
\text { belirlemek, geliştirmek, uyumlaştırmak ve rehberlik hizmeti vermek, } \\
\text { ikincil mevzuatı hazırlamak". }\end{array}$ & 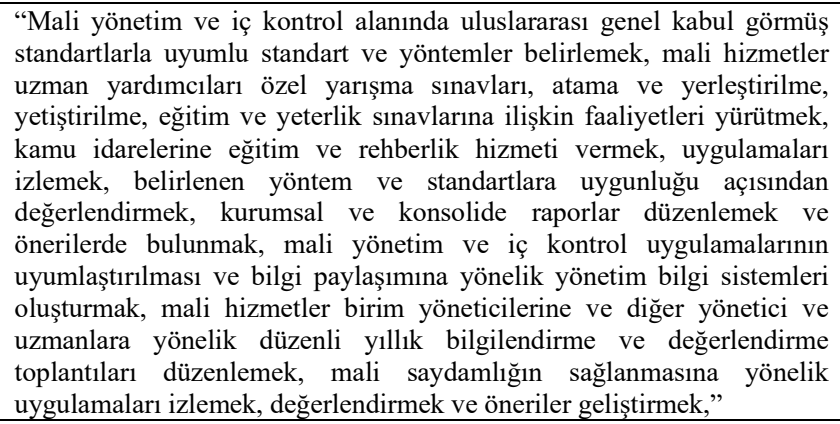 & $\mathrm{X}$ \\
\hline $\begin{array}{l}\text { "İlgili kanunlardaki hükümler saklı kalmak kaydıyla, kamu maliyesi } \\
\text { ilkelerinin uygulanmasına ilişkin usul ve esasları belirlemek," }\end{array}$ & $\mathrm{X}$ & $\mathrm{X}$ \\
\hline $\begin{array}{l}\text { "Kamu idarelerinin bütçelerinin stratejik planlarda belirlenen performans } \\
\text { göstergelerine uygunluğu ve idarelerin bu çerçevede yürütecekleri } \\
\text { faaliyetler ile performans esaslı bütçelemeye ilişkin diğer hususları } \\
\text { belirlemek", }\end{array}$ & $\mathrm{X}$ & $\begin{array}{l}\text { "Cumhurbaşkanı tarafindan belirlenen temel hedef, ilke ve amaçlar } \\
\text { çerçevesinde performans programlarının ve faaliyet raporlarının } \\
\text { hazırlanması, uygulanması ve izlenmesine ilişkin genel ilke, esas ve } \\
\text { usulleri tespit etmek; uygulamayı yönlendirmek, izlemek ve } \\
\text { değerlendirmek," }\end{array}$ \\
\hline $\begin{array}{l}\text { "Merkezi yönetim bütçe kanununun uygulamasına ilişkin olarak; } \\
\text { harcamalarda tasarrufu sağlamak, tutarll, dengeli ve etkili bir bütçe } \\
\text { politikası yürütmek içingelir ve giderlere ilişkin kanun, tüzük, yönetmelik } \\
\text { ve kararnamelerle belirlenmiş konularda uygulamaları düzenlemek üzere } \\
\text { gerekli önlemleri almak, standartları belirlemek, sınırlamalar koymak, } \\
\text { kamu istihdam politikasını belirlenmesine ve uygulanmasına yön } \\
\text { vermek, bütçe harcama ve gerçekleşmelerini izlemek, ödeneklerin } \\
\text { dağıtım ve kullanımını belirli esaslara bağlamak ve bu hususlarda kamu } \\
\text { idareleri için uyulması zorunlu düzenlemeleri yapmak," }\end{array}$ & 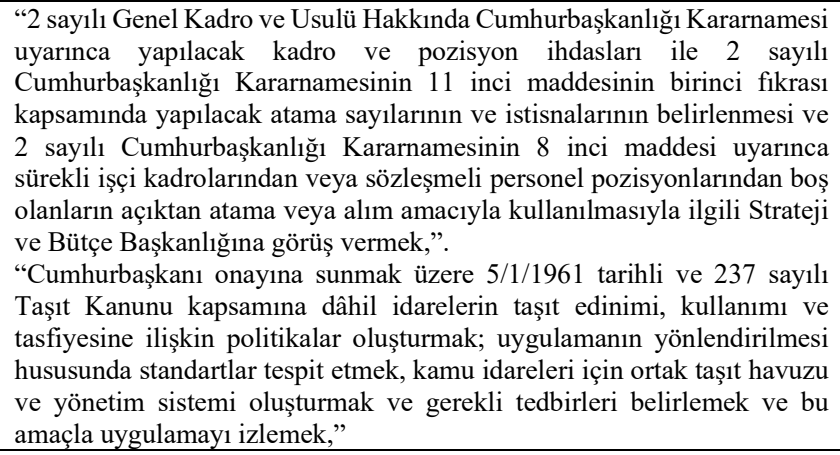 & $\begin{array}{l}\text { "2 sayılı Cumhurbaşkanlığı Kararnamesi kapsamına giren kurumların; } \\
\text { kadro ihdas tekliflerini incelemek, sürekli işçi kadroları ile sözleşmeli } \\
\text { personel pozisyonlarından boş olanları açıktan alım amaciyla } \\
\text { kullanılmasına izin vermek, memur kadrolarına açıktan veya nakil } \\
\text { suretiyle yapabilecekleri yıllık atama sayısı ile buna ilişkin usul ve } \\
\text { esasları belirleneceği Cumhurbaşkanlığı Kararına dair teklifi } \\
\text { hazırlamak," }\end{array}$ \\
\hline $\begin{array}{l}\text { "Genel yönetimin tüm gelir ve giderleri ile borç ve mali imkanlarının } \\
\text { tespitinin ve takibinin yapılabilmesi amacıyla, genel yönetim } \\
\text { kapsamındaki kamu idareleri ve merkezi yönetim bütçesinden yardım } \\
\text { alan kurum, kurulus, vakıf ve dernekler ile benzeri teşekküllerden; gelir } \\
\text { ve gider tahminlerini, mali tablolarını, birbirleriyle olan borç ve alacak }\end{array}$ & $\mathrm{X}$ & $\mathrm{X}$ \\
\hline
\end{tabular}




\begin{tabular}{|c|c|c|}
\hline & & \\
\hline $\bar{X}$ & $\mathrm{X}$ & $\begin{array}{l}\text { "Kamu yatırım projelerinin uygulanmasına ilişkin usul ve esasları } \\
\text { belirlemek, bu projelerin etkili, etkin, ekonomik ve verimli olmasını ve } \\
\text { zamanında tamamlanmasını sağlamak üzere gerekli tedbirleri alarak } \\
\text { uygulamayı yönlendirmek, uygulamayı izlemek, yıl içinde gerekli } \\
\text { değișiklik işlemlerini yapmak," }\end{array}$ \\
\hline $\mathrm{X}$ & X (Muhasebat Genel Müdürlüğü) & $\begin{array}{l}\text { "Hazine ve Maliye Bakanlığı tarafindan hazırlanan kesin hesap kanun } \\
\text { teklif taslağını inceleyerek nihai teklif taslağı haline getirmek," }\end{array}$ \\
\hline $\bar{X}$ & $\mathrm{X}$ & $\begin{array}{l}\text { "Kamu personeline ilişkin verileri temin ve konsolide etmek, personel } \\
\text { istihdamina dair konularda kadro, pozisyon ve iş analizleri yapmak, } \\
\text { standartlar belirlemek," }\end{array}$ \\
\hline $\mathrm{X}$ & $X$ & $\begin{array}{l}\text { "Kamu personelinin mali ve sosyal hakları ile merkezi yönetim } \\
\text { kapsamındaki kamu idarelerinin personel giderlerine ilişkin hesaplamaları } \\
\text { yapmak." }\end{array}$ \\
\hline
\end{tabular}

Kaynak. 13 Sayılı Strateji ve Bütçe Başkanlığı Teşkilatı Hakkında Cumhurbaşkanlığı Kararnamesi, BÜMKO 2015 Yılı Faaliyet Raporu s.2-3 ve Hazine ve Maliye Bakanlığı Kamu Mali Yönetimi ve Dönüşümü Genel Müdürlüğü sayfasından alınmıştır (https://www.hmb.gov.tr/bumkonun-gorevleri). 
Tablo 3

\section{BÜMKO, KMYD ve SBB Karşılaştırmalı Teşkilat Yapısının Karşılaştırılması}

\begin{tabular}{|c|c|c|c|}
\hline Bütçe ve Mali Kontrol Genel Müdürlüğü & Kamu Mali Yönetimi ve Dönüusümü Genel Müdürlüğü & Strateji ve Bütçe Başkanlığı (Eski) & Strateji ve Bütçe Başkanlığı( Yeni) \\
\hline İnsan Kaynakları ve Geliştirme Dairesi & İnsan Kaynakları ve Mali Hizmetler Dairesi & & \\
\hline \multirow[t]{2}{*}{ Kadro Dairesi } & Kadro Analizleri Dairesi & & \\
\hline & Kamu Personel Giderleri Analiz Dairesi & & \\
\hline Personel Mevzuat Dairesi (I) (II) & Personel Mevzuatı Dairesi & Kadro ve Pozisyon İșlemleri Dairesi (I) (II) (III) & Kamu Personeli Verileri Analiz Dairesi/Bilgi Sistemi Dairesi \\
\hline Sağlık ve Sosyal Güvenlik, Isş Hukuku Mahalli İdareler ve $\mathrm{K}$ & Sosyal Güvenlik Mevzuatı ve İş Hukuku Dairesi & & \\
\hline Bütçe Politikası ve Uluslarası Ilişkiler Dairesi & Bütçe Politikası Koordinasyon Dairesi & Bütçe Hazrllk ve Uygulama Koordinasyon Daire & e Bütçe Hazrllk ve Uygulama Koordinasyon Dairesi \\
\hline Harcirah ve Taşıt Dairesi & Kamu Taşıt Politkası ve Yönetim Dairesi & & \\
\hline Sağlık ve Sosyal Güvenlik, İș Hukuku Mahalli İdareler & Sağlk ve Sosyal Güvenlik Dairesi & Sağlık, Çalışma ve Sosyal Hizmetler Dairesi & Sağlık, Çalışma ve Sosyal Hizmetler Dairesi \\
\hline Harcırah ve Taşıt Dairesi & Kamu Alımları ve Harcırah Dairesi & & \\
\hline Kamu Į̣̇ Mali Kontrolü Eğitim ve Rehberlik Dairesi & Kamu Į̣̇ Denetim Koordinasyon Dairesi & & \\
\hline İç Denetim Merkezi Uyumlaştırma Dairesi & İç Kontrol Merkezi Uyumlaştırma Dairesi & & \\
\hline \multirow[t]{2}{*}{ Kanunlar ve Parlamento İlişkileri Dairesi } & Kanunlar ve Parlamento Illiskileri Dairesi & & \\
\hline & Destek ve Transferler Dairesi & & \\
\hline \multirow[t]{3}{*}{ Bütçe Araștırmaları ve Analizleri Dairesi } & Gelir Analizleri Dairesi & Kamu Harcamaları Analiz Dairesi & Kamu Harcamaları Analiz Dairesi \\
\hline & Ortak Kamu Giderleri Analiz Dairesi & & \\
\hline & Yatrrm Projeleri Analizi Dairesi & & \\
\hline İdari Mevzuatı Geliștirme Dairesi & İdari Mevzuatı Geliștirme Dairesi & Mevzuat Düzenlemeleri Koordinasyon Dairesi & İdari Mevzuat Koordinasyon Dairesi \\
\hline \multicolumn{4}{|l|}{ Mali Yönetim ve Kontrol Dairesi } \\
\hline \multicolumn{4}{|l|}{ Avrupa Birliğine Uyum Dairesi } \\
\hline \multicolumn{4}{|l|}{ Kamu Almları Koordinasyon Dairesi } \\
\hline Eğitim, Kültür ve Spor Hizmetleri Dairesi & & Eğitim, Kültür ve Spor Hizmetleri Dairesi & Eğitim, Kültür ve Spor Hizmetleri Dairesi \\
\hline Genel ve Adalet Hizmetleri Dairesi & & Genel Kamu Hizmetleri Dairesi & Genel Kamu Hizmetleri Dairesi \\
\hline \multirow[t]{6}{*}{ Yükseköğretim Hizmetleri Dairesi } & & Yükseköğretim Hizmetleri Dairesi & Yükseköğretim Hizmetleri Dairesi \\
\hline & & Savunma ve Güvenlik Hizmetleri Dairesi & Savunma ve Güvenlik Hizmetleri Dairesi \\
\hline & & Ekonomik Hizmetler Dairesi & Ekonomik Hizmetler Dairesi \\
\hline & & Gelir Bütçesi Dairesi & Gelir Bütçesi Dairesi \\
\hline & & Altyapı ve Çevre Hizmetleri Dairesi & Altyapı ve Çevre Hizmetleri Dairesi \\
\hline & & & Kesin Hesap ve Dı̣ Denetim Koordinasyon Dairesi \\
\hline & & & Kanunlar ve Kararnameler Koordinasyon Dairesi \\
\hline
\end{tabular}

Kaynak. BÜMKO, KMYD ve SBB’nin Teşkilat Yapısının Karşılaştırılması. Strateji ve Bütçe Başkanlığı 2018 Yılı Faaliyet Raporu s. 6, Strateji ve Bütçe Başkanlığı 2022 Performans Programı s.7, (aktr. Strateji ve Bütçe Başkanlığı, kişisel görüşme, Aralık 2021), BÜMKO 2015 Yılı Faaliyet Raporu s.6 ve Hazine ve Maliye Bakanlığı Kamu Mali Yönetimi ve Dönüşümü Genel Müdürlüğü internet sayfasından alınmıştır.

\section{Sonuç}

Strateji ve Bütçe Başkanlığı ile Kalkınma Bakanlığı arasında ilişkinin net bir biçimde çizilmesine rağmen, aynı durumun SBB ile Hazine ve Maliye Bakanlığı için gerçekleşmediğini söylemek yanlış olmayacaktır. SBB, Kalkınma Bakanlığından farklı olarak plan ve program hazırlanma sürecini, Cumhurbaşkanı tarafından belirlenen amaç ve ilkeler çerçevesinde belirleyen bir kurumdur. Kalkınma Bakanlığından farklı olarak SBB gelişmekte olan ülkelere kalkınma konusunda önderlik misyonuna sahiptir ve İslami ülkelerle ticari ilişkilerin geliştirilmesi kurumun görevleri içinde sayılmıştır. Kalkınma Bakanlığı uluslararası ilişkiler çerçevesinde İSEDAK ile ilgili görevlerini yürütürken, İSEDAK SBB'de olduğu gibi Kalkınma Bakanlığının görevleri içerisinde ayrıca sayılmamıştır.. SBB, Kalkınma Bakanlığından farklı olarak bölgesel planlama konusunda da görev sahibi değildir. Kalkınma Bakanlığı ile merkezi ve bölgesel planlama birleştirilirken, SBB'nin kurulması ile tersi gerçekleştirilmiştir. SBB'nin görevleri arasında, Kalkınma Bakanlığının sahip olduğu özel sektörü yönlendirme rolü yoktur.

BÜMKO doğrudan SBB'ye dahil olmamıștır. BÜMKO’nun görevleri arasında sayılan kamu alımlarına dair politika geliştirmek, iç kontrol, taşıt alımına dair çeşitli görevleri yerine getirmek, kamu harcamalarını etkinlik verimlilik gibi ilkeler çerçevesinde takip etmek gibi hususlar 
Hazine ve Maliye Bakanlığı içerisinde KMYD’nin görevleri olmuştur. KMYD, BÜMKO’da olmayan ancak yine Maliye Bakanlığının yaptığı Gelir Bütçesi Teklifi Taslağını hazırlamakla yükümlü kılınmıştır. KMYD, bütçenin gelir kısmında, SBB ise kamu harcamaları kısmında daha önce çıkmaktadır. Keza her iki kurumun teşkilat yapısının buna uygun olduğunu görmek mümkündür. Kamu Harcamaları Analiz Dairesi SBB içindeyken, Gelir Bütçesi Analiz Dairesi KMYD içindedir. BÜMKO içindeki harcama daireleri birkaç küçük değişiklikle SBB’ye dahil olmuştur. Kamu harcamalarının tasarruf bağlamında takibi iki kurumun ortaklaştığı bir husus olarak görülmektedir. SBB bütçe politikası oluşturmada çatı bir görev üstlenmiştir. OVP ve OVMP şimdiki biçimiyle OVP her iki kurumun ortak hazırladığı bir metindir. Ancak bu metinin hazırlanmasında da ağırlığın farklılaşabildiği görülmektedir. Kamu personeli politikasına dair yetkinin Cumhurbaşkanlığına Bağlı Kuruluş statüsünde olan SBB'ye ve ardından Cumhurbaşkanına doğrudan bağlı Cumhurbaşkanlığı İdari İşler Başkanlığına devredilmesi oldukça dikkat çekicidir. Vurgulanması gereken bir diğer husus BÜMKO’nun kamu harcamalarının takip edilmesi amacıyla genel yönetim içerisindeki kurumlardan yardım alan dernek ve vakıfların mali durumlarına dair bilgi isteme görevinin KMYD ve SBB'nin görevleri içerisinde yer almamasıdır.

\section{Kaynakça}

1 Sayılı Cumhurbaşkanlığı Teşkilatı Hakkında Cumhurbaşkanlığı Kararnamesi.

13 Sayılı Strateji ve Bütçe Başkanlığı Teşkilatı Hakkında Cumhurbaşkanlığı Kararnamesi.

540 sayılı Devlet Planlama Teşkilatı Kuruluş ve Görevleri Hakkında Kanun Hükmünde Kararname.

641 sayılı Kalkınma Bakanlığının Teşkilat ve Görevleri Hakkında Kanun Hükmünde Kararname.

Akbey, F. (2020). Cumhurbaşkanlığ Hükûmet Sisteminde Bütçe Hakk1 ve Kanunu. International Journal of Public Finance, 5 (1) , 1-26.DOI: 10.30927/ijpf.676534

Albayrak, S. (2020). Türkiye'de Kamu Personel Yönetiminin Yeni Kurumsal Yapısı ve Kamu İstihdamının Yeni Görünümü. Ankara Üniversitesi SBF Dergisi, 75 (4),1517-1549. DOI: 10.33630/ausbf.814996

Barbak A. (2010). Gelir İdaresinde Yeniden Yapılanma ve Özerklik Tartışmaları (1980-2010). YBAD Lisansüstü Seminer Çalışmaları, No: 8, Nisan 2010, http://yonetimbilimi.politics.ankara.edu.tr/wpcontent/uploads/sites/732/2013/07/abarbak.p df.

Bedirhanoğlu, P. (2019). Cumhurbaşkanlığg Hükümet Sistemi ve Türkiye'de Ekonomi Yönetiminin Dönüşümü. 
https://www.researchgate.net/publication/331960104_Cumhurbaskanligi_Hukumet_Siste mi_ve Turkiye'de_Ekonomi_Yonetiminin Donusumu

BÜMKO (2016). 2015 Yll $\quad$ Faaliyet Raporu. Alınan yer https://ms.hmb.gov.tr/uploads/2019/03/B\%C3\%BCt\%C3\%A7e-Mali-Kontrol-GenelM\%C3\%BCd\%C3\%BCrl\%C3\%BC $\% C 4 \% 9 F \% C 3 \% B C-2015-Y \% C 4 \% B 11 \% C 4 \% B 1-$ Faaliyet-Raporu.pdf

Coşkun, B. \& Yıldırım, Ç. (2018). Türkiye'de Stratejik Planlama: Son Dönem Gelişmelerin İncelenmesi. Strategic Public Management Journal, 4 (8), 1-16. DOI: $10.25069 /$ spmj.492784

Çalışkan, A. , Kaya, P. B. \& Malak, M. (2020). Cumhurbaşkanlığg Hükümet Sisteminin Bütçe Sürecine Etkisi. Ankara Hacı Bayram Veli Üniversitesi Íktisadi ve İdari Bilimler Fakültesi Dergisi, 22(3), 721-736. Alınan yer https://dergipark.org.tr/tr/pub/ahbvuibfd/issue/58605/802799

Durdu, M. (2020). Bütçe Hakkının Cumhurbaşkanlığı Sistemindeki Görünümü ve Latin Amerika Ülkeleri ile Mukayesesi. Liberal Düşünce Dergisi, 25(99), 49-78. DOI: 10.36484/liberal.739812

Hazine ve Maliye Bakanlığı (2021). Bütçe ve Mali Kontrol Genel Müdürlüğü. Alınan yer https://www.hmb.gov.tr/bumko-tarihce

Ercan, T. (2021). Türkiye'de Mali Reform Kapsamında Performans Esaslı Program Bütçeye Geçiş Süreci. Anadolu Üniversitesi İktisadi ve İdari Bilimler Fakültesi Dergisi, 22 (3), 35-52. DOI: 10.53443/anadoluibfd.949215

Kalkınma Bakanlığı (2015). 2014 Faaliyet Raporu. Alınan yer https://www.sbb.gov.tr/wpcontent/uploads/2018/11/Kalkinma Bakanligi 2014 Yili Faaliyet Raporu\%E2\%80\%8B . pdf

Kırışık, F. (2020). Cumhurbaşkanlığı Hükümet Sistemiyle Kamu Yönetiminin Geliştirilmesi. Alınan $\quad$ yer https://www.researchgate.net/publication/347896031 CUMHURBASKANLIGI HUKU MET SISTEMIYLE KAMU YONETIMININ GELISTIRILMESI Development of P ublic_Administration_with the Presidential_Government_System

Küçükaycan, D. \& Celikay, F. (2020). Bütçe Teorisi Perspektifinden Cumhurbaşkanlığg Hükümet Sisteminin Bütçeleme Süreci ve Bütçe Hakkı Üzerindeki Etkileri. Alınan yer (PDF) Bütçe Teorisi Perspektifinden Cumhurbașkanlığ Hükümet Sisteminin Bütçeleme Süreci ve Bütçe Hakk1 Üzerindeki Etkileri (researchgate.net)

Oyan, O. (2019).Yeni Anayasa ve Yeni Devlet Yapılanması. Çalışma ve Toplum,60(1): 105-125, Alınan yer https://app.trdizin.gov.tr/publication/paper/detail/TXpBeE5UZ3pNdz09 
Övgün, B. (2011). Türk Kamu Yönetiminde Yeni Bir Örgütlenme: Kalkınma Bakanlığı. Ankara Üniversitesi SBF Dergisi, 66 (03) , 263-281. DOI: 10.1501/SBFder_0000002222

Soydan, A. (2020). Hazine-İ Celile... Nizamname 'Sinden, Kamu Mali Yönetim Ve Kontrol Kanun'a Uzanan Modern Türk Mali Yönetimi'nin, Cumhurbaşkanlığı Hükümet Sistemi Mali Reformları Kapsamında İncelenmesi. Bandırma Onyedi Eylül Üniversitesi Sosyal Bilimler Araştırmaları Dergisi, 3 (2), 201-220. DOI: 10.38120/banusad.837225

Strateji ve Bütçe Başkanlığı (2019). 2018 Faaliyet Raporu. Alınan yer https://www.sbb.gov.tr/wpcontent/uploads/2021/03/Strateji ve Butce Baskanligi 2018 Yili Faaliyet Raporu.pdf

Temel, R. (2019). Cumhurbaşkanlığı Hükümet Sistemi'nin Türk Maliyesine Getirdiği Yenilikler. Akademik Bakış Uluslararası Hakemli Sosyal Bilimler Dergisi, (71), 13-29. Alınan yer https://dergipark.org.tr/tr/pub/abuhsbd/issue/44002/541860

Ün, L. (2021). Cumhurbaşkanlığı Hükümet Sisteminin Türk Kamu Maliyesine Etkisi. Abant Sosyal Bilimler Dergisi, 21 (2) , 299-315. DOI: 10.11616/basbed.vi.895024

Yavuz, E., Özgül, H. B. \& Susam, N. (2021). Türk Bütçe Sistemindeki Değişimler ve Performans Esaslı Program Bütçe Sistemine Geçiş. Maliye Çalışmaları Dergisi,(65), 115-137. DOI: $10.26650 / \operatorname{mcd} 2021-889262$

Yegen, B. (2020). Cumhurbaşkanlığı Hükümet Sistemi Kapsamında Bütçe Sürecinin Analizi. Dokuz Eylül Üniversitesi Sosyal Bilimler Enstitüsü Dergisi, 22 (1), 151-170. DOI: 10.16953/deusosbil.544721

Yılmaz, H. H. \& Akdeniz, İ. (2020). Cumhurbaşkanlığı Hükümet Sistemi İle Değişen Kamu Mali Yönetim Sisteminde Program Bazlı Bütçe Sistemine Yönelik Bir Yapılandırma Önerisi. Saylştay Dergisi, (117), 87-114. Alınan yer https://dergipark.org.tr/tr/pub/sayistay/issue/61573/919318 